\title{
Some Key Principles of Multinational Military Education
}

\author{
James S. Corum *
}

\section{Introduction}

Education is something that touches every single member of the military profession, and is important for the civilians who work with the military as well. Military education is something with which everyone in the military has some direct experience. After all, one could not get to top military positions today without attending staff college courses, and often war college-level courses, taught in military institutions. Higher military education - the focus of this article - is the education that takes place at the rank of major and above and includes the joint staff college courses as well as courses at the strategic level designed for colonels and generals.

National armed forces and military education institutions create mission statements defining the institutional and individual goals of each course in higher military education. The aims of the higher military education institutions in the West are generally similar, with mission statements that reflect the need to develop officers who are critical thinkers and problem solvers, who will be prepared for higher command and to serve effectively in national and multinational staff positions. But while the goals are clear, the process of achieving those goals is usually not as explicitly laid out. As a practitioner, having spent the last twenty-two years as an academic involved in higher-level military education, I have to focus on the process. From this experience I will lay out some principles that are essential to meet the goals of educating officers to meet tough challenges. While most of the principles set out here are basic to all higher military education institutions, there are a few principles that apply specifically to multinational institutions.

There are a few truly multinational institutions in the Western nations, and it is likely that in the future there will be more. This reflects the realities of modern operations. In the future, operations such as Libya and Afghanistan that involve multinational staffs and do not necessarily have a single lead nation will likely be the norm. Educating midrank and senior officers to operate in a multinational environment is already essential.

Multinational military education is the central focus of the Baltic Defence College in Tartu, Estonia, which is a unique institution in that it is equally owned and operated by three nations: Latvia, Estonia and Lithuania. Because each of the Baltic countries alone did not have the resources to offer a top-tier higher military education for its officers, in 1999 the three Baltic States decided to pool their resources and expertise and create a single staff college that would provide higher courses for officers and selected civilians. The result is a comprehensive institution that offers a year-long joint staff course to offi-

James S. Corum, Ph.D., is Dean of the Baltic Defence College in Tartu, Estonia. From 1991 to 2004, he was a professor at the United States Air Force School of Advanced Air and Spacepower (SAASS) at Maxwell AFB. In 2005 he offered a lecture course at the British Joint Staff College in Shrivenham. From 2005-08 he was a professor at the U.S. Army Command and General Staff College in Fort Leavenworth, Kansas. 
cers not only from the Baltic States, but also from NATO, EU, and partner nations. In addition, the Baltic Defence College (where the author of this article is Dean) runs a half-year course for colonels and higher-level civilians as well as a half-year course for civilian members of the defense and foreign ministries. Based on the experience of the Baltic Defence College, this article will lay out some of the key principles that guide our planning and development.

The insights presented here are not simply those of an American, or European, or an American who works for Europeans. They are the insights of a military educator who works in a highly multinational environment. There is one thing that a long period of working in a completely multinational environment will teach you - that the fundamentals of the military profession transcend nation and culture. Still, there are some aspects of education that apply especially to multinational environments, and I will discuss these later in this article.

While all professional officers attend staff college and higher military education courses sometime in their career (usually several times in their career), they only understand military education through their experience as a student and, as students, they were primarily focused on the task at hand, which was to do well in their courses and graduate. Afterwards, while most officers use the skills they learned and developed in the higher-level courses throughout their careers, few officers think about the process of military education. Yet because military education is so central to the military profession, and so central to the ethos of military leadership, it is essential that senior leaders take some time to think seriously about the principles that ought to guide higher military education.

\section{The Power of Military Education}

One lesson to learn from modern military history is the central importance of higher officer education to the fighting power of the armed forces. In short, the lesson is clear: military education can mean the difference between victory and defeat, success and failure. The Prussians invented the concept of higher officer education in the nineteenth century with the development of the Kriegsakademie in Berlin, a rigorous three-year course of education in the operational and strategic military arts that prepared officers to join a small elite general staff corps. That highly educated general staff corps, working with a common doctrine and understanding, developed the war plans and operational training and concepts that made the Prussian Army a superior force on the battlefield. The Kriegsakademie-educated general staff deserves a great part of the credit for Prussia's ability to mobilize efficiently and move swiftly, using the new inventions of the railroad and the telegraph, and to bring powerful forces together for decisive strokes against Prussia's powerful (but less intellectually capable) enemies in the war of 1866 that was fought against the central and south German states allied with Austria. Four years later, the united German forces, again led by its well-educated general staff, decisively defeated the well-trained and well-armed French Army that had been considered the best army in Europe. The superiority of Prussian war planning and mobilizationmost notably, the Prussians' ability to effectively coordinate large forces on broad 
fronts - greatly impressed all the armies of the major powers. Within a few years, every other major power had copied the German model of a general staff and higher military education.

In World War I and World War II, the excellence of the German system of higher military education proved an important factor in the course of each war. The German Army was usually greatly outnumbered in terms of manpower and resources, yet, unit for unit, the Germans proved superior on the battlefield through much of both wars. However, the operational excellence produced by the German military education system was offset by the lack of education and competence of the German armed forces at the strategic level. While the German Army was arguably superior in their conduct of operations in both World Wars, the same military leaders failed badly at the strategic level of war. In World War II, the Germans proved markedly incapable of efficiently mobilizing the economy for the war. In both World Wars, the German military often proved inept in terms of managing grand coalitions. This is partly explained by the singleminded focus of German military education on the operational level of war. Except for a short-lived experiment in developing a Wehrmacht Akademie to educate a strategic staff between 1935 and 1938, there was little interest in developing a corps of strategic war planners.

In contrast, one of the great strengths of the United States in World War II was the effectiveness of U.S. economic mobilization for war and in developing highly effective grand strategic plans for waging a global coalition war. This effectiveness of the U.S. at the strategic level did not come about by chance. Through the interwar period, the United States Army War College provided a superb one-year course for a small cadre of lieutenant colonels and colonels in strategic war planning. From 1934 to 1940, U.S. Army War College students and faculty worked closely with the U.S. Army General Staff to develop war plans and war game scenarios that involved national-level planning for coalition warfare against Germany and Japan. It was the War College and its yearly exercises that formed a great part of the intellectual foundation for the successful U.S. war plans developed in 1941. In addition to the War College, the Army Industrial College, founded in Washington, D.C. in 1924, provided an advanced education in defense planning and economics to a small cadre of officers and civilians in the interwar period. The Army Industrial College was a unique institution in that it focused on the problems of mass industrial mobilization. When war finally came to the United States in 1941, it had an educated cadre of officers and specialists for whom the problems of resource management, industrial mobilization, and global coalition war were not new.

The U.S. military education system was reformed considerably after the Vietnam War, as the U.S. Army created a new school for operational planners at Fort Leavenworth, Kansas, called the School of Advanced Military Studies (SAMS). SAMS would provide a small group of exceptional officers with a year-long course in operational theory and planning after the officers had completed the general staff course. In the 1990, the Marine Corps followed with their own version of the course, the School of Advanced Warfighting Studies (SAWS). In 1991, the U.S. Air Force also followed with its elite operational/strategic course called the School of Advanced Airpower Studies 
(SAAS). These were additions to the already extant staff college course run by all services and the war colleges. In Washington, the National War College served to provide a strategic education across all of the branches of the armed forces.

There is no question that the U.S. military did a superb job in educating its officers to face the Cold War threat of conventional and nuclear warfare against the massed forces of the Warsaw Pact. The ability of the U.S. forces to wage coordinated joint warfare in the Gulf War of 1991 - in which the Iraqi forces were quickly crushed with minimal casualties to U.S. forces - dramatically demonstrates the effectiveness of the U.S. system of education in the operational arts. The problem was that, in the post-Vietnam era, the U.S. military had become a one-trick pony, wonderfully trained in all aspects of conventional warfare, but largely untrained and untutored in other forms of conflict. Most notably, the U.S. military leadership studiously ignored irregular forms of warfare, even though events around the world showed that such conflicts abounded.

While the U.S. military readily won the conventional battles in Iraq in 2003 and the initial campaign to topple the Taliban in Afghanistan in 2001, the U.S. military found itself intellectually unprepared to fight the resulting insurgencies or to manage a military occupation. The U.S. military spent three years in Iraq learning the basics of counterinsurgency from scratch, having forgotten whatever it may have learned in the jungles of Southeast Asia thirty years earlier. In Afghanistan, the U.S. forces were unprepared to take the correct action to prevent the growth of a major insurgency after having achieved a conventional victory. Indeed, the long period that it took for the U.S. military to adapt to a very old and very well-known form of warfare is largely attributable to the general failure of the U.S. military's education institutions to educate its officers in the basics of insurgency and counterinsurgency prior to becoming involved in such conflicts.

\section{Core Principles of Military Education}

\section{Quality Education Requires a Comprehensive Vision}

To get military education right, armed forces must have a clear and comprehensive vision of the military education and training system for officers - from the cadet course training lieutenants to the colonels' course to educate strategists.

Most Western nations have a four-phase system of military education that follows a common pattern. Phase one is the course in the military academy or within a civilian university that leads to a commission as a lieutenant. Phase two is the intermediate officer education for lieutenants and captains, during which officers take courses in a specific field of military specialty as well as company-level leadership courses. This phase usually includes a basic staff course of three to six months to teach junior officers the basics of battalion and brigade staff functions.

It is phases three and four that are of concern here, as these phases constitute the higher-levels of education for officers. Phase three is commonly a one- to two-year general staff course in which the student (usually a major) is educated in the operational arts and learns how to plan and conduct joint operations at the division and corps levels. While the operational level of war is the focus during this phase, the student also re- 
ceives some education in strategy and political economic issues, since an effective operational planner must be able to understand and translate strategic intent into practical operational plans.

Phase four is a course of varying duration (four to twelve months) for lieutenant colonels and colonels to educate them at the strategic level of conflict. The focus of the strategic course is less military than the general staff course, and concerns itself more with national and coalition strategy. To master this phase, an officer needs to be educated in international relations, the national strategic process, defense management, and economics and other such fields. This phase involves learning the difficult and highly complex mechanisms that combine the intent of the civilian leadership with the other civilian and military means to achieve national policy goals.

This general construct of four phases is widely accepted in the NATO nations as sound. There is little debate about the appropriate content for the education of lowerlevel officers in phases one and two. This is where every officer has to learn the fundamentals of his profession. However, the content of the higher-level phases of military education is not easy to determine, and getting this right requires a sound vision and direction from the national defense ministry and top defense staffs. Getting the content of higher education wrong - as happened in the U.S. when irregular warfare was virtually eliminated from the military education curriculum in the U.S. staff colleges from 1973 to 2001 - means coming to the battlefield only to find that everyone is playing by a completely different set of rules, and no one has shown you the rulebook.

Getting the vision right takes considerable effort on the part of the defense staffs and the educational institutions. The defense staffs need to have an end state in mind - an understanding of what types of war and operations the armed forces are likely to face in the next decades. Certainly any reasonable assessment of the future ought to include the assumption that conflicts with irregular forces will be likely. Another sound assumption is that Western or NATO armed forces ought to be prepared to undertake a variety of military intervention operations. These operations will range from relatively benign environments to situations where heavy combat is likely. Of course, armed forces need to also focus on educating officers to face major conventional war scenarios as well. This means that the curricula of higher-level military education courses need to be balanced, and to include a variety of forms of warfare. Getting the right balance in the curriculum is a difficult task and requires coordination and dialogue between the top command levels and the leaders of the military education establishment.

One of the great dangers in military education is the problem of popular fads or interests that take hold in the imagination of the political and military leadership and are translated into demands that the military education institutions reorient themselves to follow the latest trend (or the most recent form of conflict). While military leaders are legally bound to obey their civilian leaders, they are also responsible for giving their civilian leaders clear and accurate advice on military matters, even if that advice is not what the politicians wish to hear. Military leaders ought to be careful of imposing fiats and study of the hot trends of the moment into the staff college curriculum, since for every large block of hours that is added to the curriculum, the military educator will 
have to cut elsewhere. The danger of too readily adopting faddish thinking is a genuine problem in U.S. military education, and I have also heard some complaints from European educators as well.

To maintain a sound education system, curricula ought to be developed by education professionals, in dialogue with their defense staffs. But micromanagement of curricula by defense staffs, in every case I have seen, has led to a weakening of the curriculum and the educational process. Getting the vision right, and seeing that the courses and curriculum that we have are in accordance with an accurate vision of the future needs of the Baltic armed forces, is the most important job that the leaders of the Baltic Defence College have.

\section{Quality Military Education Takes Time}

It is a simple and understandable fact that military and civilian organizations are loath to release their best officers and civil servants for long periods in order that they can obtain a professional education. It is also understandable that most commanders and civilian leaders are usually focused on the immediate and short-term tasks of their organizations. It is a rare leader or organization that can look to the long term.

It is also important to recognize that effective mid-level and senior leaders cannot stop their professional education at the B.A. level, but need to have a regular and wellconceived program of professional learning throughout their whole career. Indeed, with the establishment of officer specialist schools and general staff colleges and, finally, war colleges in the nineteenth century, the military was the first major institution to recognize that an ethic of life-long learning and education was necessary to achieve success in the long term.

In short, we are faced with competing claims: immediate requirements versus the long-term development of military and civilian organizations. Senior commanders are required to think of the long-term effectiveness of their organizations, even if the civilian and military culture seems to always insist on the primacy of short-term interests. Thinking in the long term, however, requires the creation of a career military education system that will allow officers and selected defense and foreign ministry civilians to be unmoored from their organizations at regular intervals to participate in higher education courses.

The question of what amount of time is needed for intermediate education has been answered in different ways by different Western nations. Many of the NATO nations have a three to four-year military academy program in which the student graduates as a second lieutenant with a civilian-accredited Bachelor's degree. The three Baltic States have such a program. Other NATO nations also have means by which people with Bachelors' degrees can take a shorter course that will lead to a commission as a lieutenant. NATO nations and the Baltic States also have intermediate officer courses for lieutenants and captains, lasting from a few weeks to several months. The two lower phases of officer education are very similar in the NATO and Western nations, and are a model that has proven very effective. 
The real debate is about the amount of time that is needed for a higher military education. Some nations, such as Austria, have a long period - three years - of general staff education. More common (and the NATO norm) is a one-year general staff course, typically offered to majors. This is the model followed by the Baltic States and the Baltic Defence College. At least one year is necessary to see that a mid-grade officer receives a full grounding in the theory and doctrine and requirements of the operational level of war. Beyond this, some countries (including the U.S.) have an extra year for selected intermediate officers (SAMS, SAWS, SAASS), in which officers take an intensive course in higher-level planning and strategy. This small group of officers is destined to fill roles as senior planners.

Finally, in the fourth phase of military education we see the greatest degree of difference in terms of time requirements. The U.S. war colleges that offer education at the lieutenant colonel and full colonel level feature one-year courses. Other countries have shorter half-year courses for officers at the strategic level. For a decade, the Baltic Defence College has had a half-year Higher Officer Course for officers to be educated at the strategic level. However, the College is currently looking at developing a one-year war college-type of course, to be conducted in partnership with the Danish National Defence Academy. Both institutions have determined that a six-month course does not provide all the aspects needed for a high-quality strategic-level course.

The mission now, as ever, is to convince the ministries that own the Baltic Defence College that the value that can be added in a one-year course justifies taking good officers away from their duties for such a period of time. Although the short-term interests of the staff sections of MoD departments suffer when good personnel are sent away for six months or a year, the advantage of getting back officers with much higher qualifications should be worth the trouble. Although this seems obvious to professionals who are committed to military education, the case for an adequate period of high-quality military education must be made to ministries of defense again and again.

\section{Research and Education Must Be Tied Together}

An effective higher-level education that develops students' critical thinking capabilities will combine a program of research with education. Research and education are not incompatible. Indeed, the two processes reinforce each other.

In a higher-level institution, unlike an undergraduate college, you have a student body that already has a considerable degree of education as well as extensive experience. Officers going to a basic staff college course are usually ten to fifteen years into their military career. They have already held several assignments, have likely been a lower-level commander, and have experienced one or more overseas deployments. At the Baltic Defence College, almost all of our Baltic officers have been deployed to Iraq or Afghanistan, some on multiple missions. Our Western NATO officer students have all been deployed on active operations. In fact, in the last academic year (2011-12), more than two-thirds of our total student body of our Joint Staff Course had been deployed on combat operations. Our civilians also had exceptional experience. We had one Japanese Foreign Ministry aid expert in our civil servants course who had been on 
four deployments to Afghanistan. This civilian and military interaction and shared experience are tremendously valuable for the education process.

However, while experience is a great thing, it is also important to teach the students how to effectively record and assess their own experience and the experience of others. In order to develop the true critical assessment capability that is needed in higher-level leaders, we require each student to complete an extensive research and writing project. Each student in the Baltic Defence College's year-long Joint Course must complete a research paper of 8,000-12,000 words (an academic journal-length article) that employs original research. The paper must be written in English to a graduate student paper standard.

We require a research paper because being able to research a subject in depth and come to a well-defined and supported conclusion is a fundamental skill of the good staff officer. Yet the research program is intended to do more than develop the students. We see both students and faculty members as key resources for the defense ministries that employ us. The expertise found among the faculty and the students means that we have the potential to deliver high-quality research and analysis papers to the defense ministries of the Baltic States at little cost. In short, we can serve as a think tank for the Baltic States on all manner of defense and security issues.

We have asked the ministries of defense of the Baltic States to give the Joint Course a list of key questions and topics that they want to see researched and developed in some depth. We offer these to the students and encourage them to take up the proposed research topics. What we have seen in the past is that, while many of the student papers are fairly mundane (which one can expect of officers who have not previously been pushed to do research), every year several stand out as outstanding works of analysis that address issues that are important to their national ministries. Many of the research papers I have seen produced by our students are superior to some of the work done by top defense think tanks - work that costs ministries a considerable amount of money. In contrast, the research that our students produce costs their ministries nothing. The best papers are eventually published, either in our journal, or through U.S. partners. The research program at the U.S. Air Force elite school for strategists (SAASS) provides an example of the high quality work that students can do. The best papers have been published by the Air Force and have been widely circulated, and have had a considerable impact on the USAF's doctrine and policy.

\section{Do not Forget Civilian Education}

The armed forces in NATO nations and their Western-oriented partners have wisely built regular periods of professional education into the lifetime career system of their professional and even reserve officers. However, the civilian employees of the defense ministries and security services are also vital elements of the comprehensive national defense network. Indeed, no modern armed forces can operate without the support of a cadre of professional civilians who work in fields such as logistics, education, medicine, administrative support, law enforcement, and research and development. 
Yet, the same nations that recognize the value of education and systematic career development of military personnel through education rarely have a system of regular professional education for civilians that is carried out in accordance to a master plan. In general, education for civilian support staff of the armed forces is an ad hoc or "on the job" affair. Considering the key specialties that civilians have, and the need to be able to support the armed forces effectively, the idea that civilians might need an operational or higher-level education similar to that provided to key personnel in the armed forces has been generally ignored.

The Baltic States have taken a step forward in acknowledging the concept of civilian education, and the three states have tasked the Baltic Defence College to provide an operational-level course for mid-ranking civilians in the defense and foreign ministries of the Baltic States. The Baltic Defence College today runs a half-year course called the Civil Servant Course for mid-level defense ministry and foreign ministry civilians. While the course is primarily aimed at educating the civilian members of the Baltic States ministries, it has also been popular with civilians from other nations - especially the Eastern European nations that have recently joined NATO or aspire to a NATO relationship. In fact, in the ten years since the program's inception, several dozen nonBaltic personnel have graduated from the program.

The civilians who come to the course are required by their job to work closely with the armed forces, so it is necessary for them to have a close familiarity with military planning and operations. At the Baltic Defence College, the civilians in the half-year course receive a basic education in military organization and planning in the first weeks of the course. They then join with the regular Joint Staff Course and participate in the major exercises, in which there are many civilian roles to play on the planning and operational and strategic staffs. In fact, the civilians play the same roles that civilians would play in real operations. The realism of the course is enhanced for the military students, and both civilian and military students learn from each other.

The Baltic Defence College also offers a strategic-level Higher Command Course that is open to senior defense ministry and foreign ministry civilians. We have had great success in educating civilians and military personnel together in this half-year course. In the cases of both the Civil Servant Course and the Higher Command Course, our graduates return to their employers with a much better understanding of the views and roles of their counterparts. The Baltic States' defense ministries have recognized the value of educating their civilians, and today we have no problem in getting these ministries to send their civilians to us for higher-level courses, as the ministries know they will receive more capable personnel back.

However, the problem of ensuring that civilian personnel have appropriate higherlevel professional education persists. This is due to a Western military culture that does not build regular periods of training into the career path, ensuring that every period during which personnel are sent to educational institutions represents a burden for the sending agency. One of the projects that we are working on presently at the Baltic Defence College is to discuss this issue with the defense ministries of the Baltic States, in order to create the same type of four-phase educational/career professional development 
program for civilians that exists for the military officers. Over time we hope to build a model of what kind of courses, and what length of courses, the civilians in foreign and defense ministries (and other ministries that deal with national security) need at each stage in their careers. Through this project we hope to develop an appropriate model of civilian education that will provide for greater efficiency and professionalism on the civilian side of national security.

\section{Quality Military Education Requires Close Cooperation with Civilian Institutions}

If you want to have a high-quality military education, you need to locate your school close to the top civilian universities and develop a close working relationship with civilian academic institutions. In 1999, when the Baltic Defence College was established, the key consideration in locating the college was finding a location close to the top civilian education institutions. Tartu was an obvious choice, because Tartu University (established in 1632, with 15,000 students today) is one of the top educational institutions in Eastern Europe, and is rated among the top sixty universities in the European Union. By locating the Baltic Defense College only a few minutes' walk from Tartu University, the college and its students can take advantage of the superb resources and faculty of the university. For example, the Baltic Defence College is only five minutes' walk from the Tartu University library, with its five million volumes and excellent databases. Baltic Defence College students and faculty have full rights to use the Tartu University libraries free of charge. For its part, all the resources at the Baltic Defence College-which offers an excellent specialist library on defense issues and military history, as well as a number of military-related databases - are fully open to students from Tartu University.

Tartu University faculty regularly lecture at the Baltic Defence College, and several university faculty members serve as adjunct faculty. The Higher Command Course is open, at no charge, to Tartu University faculty, and Baltic Defence College faculty members have an opportunity to earn a Ph.D. in international relations at Tartu University, also without charge. In another reciprocal move, two of the Baltic Defence College's faculty members (including the dean) teach a military history course as part of the Tartu University M.A. program in cyber security.

Close cooperation with Tartu University is essential in the presentation of high-quality conferences and seminars. The Baltic Defence College opens its conferences and special academic seminars to graduate students of some Tartu University programs. The Baltic Defence College and Tartu University also have joint publication projects in subjects such as security policy and military history. This enables us to pool resources and deliver a high-quality product at a lower cost.

The modules of the Higher Command Course are recognized and accredited for graduate credits under the European Credit system. Indeed, the close cooperation with Tartu University that the Baltic Defence College enjoys was a key factor in getting international academic accreditation for the Joint Staff Course as part of the Latvian National Defence Academy M.A. program in security studies. In NATO nations, higher 
military education is carried out with an eye to seeing that it receives full civilian academic recognition and credit. This cannot be done by military institutions without close coordination and partnership with civilian universities.

By any measure the Baltic Defence College would be much weaker as an educational institution without the resources and faculty involvement of Tartu University and the close partnerships that we have established. For our part, we have offered some very useful courses, our faculty expertise, and our library resources (open to all Tartu students) as a means to make Tartu University a better academic institution. This type of civilian university and military school partnership is typical of the close civilian and military cooperation that exists at many of the high-quality NATO nation military schools. Such cooperation costs little, and is a huge plus for both sides.

\section{High Standards are Essential}

For an academic course to be worthwhile and effective, there must be high admission and course performance standards. These standards ought to be objective in nature, and should be calculated in order to maximize the effectiveness of the courses offered. If admission standards are consistently high, then the students will be able to study and conduct analysis at a more complex level from the start of the course. Syndicate and group work, which is essential in all the higher-level military courses in NATO nations, will proceed much more smoothly if the students are rigorously prepared to do the work. At the same time, a high standard for course performance must be set and enforced, even if that means failing students who are otherwise good officers but cannot meet the intellectual standards that are required. As a norm, the military standards need to be high enough to meet the best civilian accreditation standards for good graduate schools. Anything less will make the time spent in a staff college course seem unattractive to the students, and will not garner support from defense ministries.

There are few absolute rules about standards. If you set entry standards very high, as the Germans did in the 1930s and 1940s, you will end up with a cadre of general staff officers superbly educated in the operational arts, but you will also have a severe chronic shortage of general staff officers. So the best practice is to create an education system that serves the top half of the officer corps - the part of the officer corps that is best suited to advancement to higher command and staff positions.

The lowering of admission standards, or setting the bar too low, can result in longterm damage to a military service. The U.S. is a prime example of this. Beginning in 2003, the U.S. Army Chief of Staff, General Eric Shinseki, decreed that all U.S. Army majors would henceforth be sent to the residence course of the U.S. Army Command and General Staff College at Fort Leavenworth. Previously, the policy had been to send no more than the selected top half of majors to the residence course. The decision to have all majors take the course was General Shinseki's alone, and was made without input from those experienced in military education. The rationale was the United States' decision to fight two simultaneous wars (in Iraq and Afghanistan) without expanding the force, requiring all officers to be kept on a high tempo of repeated deployments. The 
General Staff Course at Fort Leavenworth became a brief training and rest break before the next deployment.

The "send all majors" attendance policy was referred to by the Fort Leavenworth faculty as the "no major left behind" program. It immediately resulted in a severe drop in the academic standards and learning performance of the U.S. Army. Previously, the faculty could assume that all the students were well prepared for an intellectually rigorous course, and could set the curriculum accordingly. Under "no major left behind," the faculty of the General Staff College (of which I was one from 2005 to 2008) complained that the academic course load had been reduced and downgraded due to the clear lack of preparation on the part of many of the students. The lack of standards was combined with pressure from the Pentagon to see that all students passed the course. These two factors resulted in far lower performance and lower expectations, as the daily syndicate work had to be brought down to accommodate the level of the less capable students, many of whom have no inclination to do serious advanced career study but suddenly found themselves required to do so.

This policy will soon be ended, and by 2014 it is planned that the U.S. Army will return to the old standard of only the top half of majors going to the residential staff college course. However, a ten-year period of low standards will certainly be felt in the U.S. Army leadership in the coming years, as far less qualified and intellectually capable officers have been promoted to higher rank. The final result is an officer corps that is generally less prepared for the difficult requirements of modern military operations and not capable of carrying out the more complex duties of strategic planning. The only remedy will have to be a drastic purge of the officer corps at the rank of major and above. Yet this remedy, although necessary, will in turn provoke a period of low morale as careers are terminated early.

The Baltic Defence College offers a sound path and some good benchmarks for standards in mid-level officer education. First of all, the Baltic Defence College requires that every officer sent by his armed forces to the Joint Staff Course have completed an intermediate officer staff course at the captain level to ensure full understanding of basic military staff procedure. Next we require that every officer pass a test in the English language, which is administered by us, to meet a NATO STANAG 3 level of proficiency. Every year some students fail the test. They are offered a retest in a few days. If they fail the retest, they are sent home as unsuitable for the Baltic Defence College. There is no pressure for the Baltic Defence College to lower this high standard.

The next standard is the core academic requirement. We require that the students pass five learning areas to graduate. Failure in one area is a failure of the course. Again, every year there will be a student or two who cannot pass all the requirements. We do everything possible to coach the weak students, but if they fail, and fail the opportunity we provide for a retest, then these students fail the course. Those who spent the year and failed do not receive a course diploma, but instead a certificate of attendance in the course. We also rigidly enforce rules against plagiarism on exams and writing assignments. Again, occasionally the Baltic Defence College has had officers that do not meet the fundamental academic ethics requirements, and we do not pass them. Compromise 
on such issues would undermine the credibility of our course and school. Ensuring the quality of our diplomas and maintaining academic credibility to a graduate school standard is an essential part of our mission to ensure that every graduate is fully qualified to serve on national and multinational staffs in higher positions. By maintaining high standards, we fulfill our duty to ensure that the Baltic States have a highly qualified higher officer cadre who can perform credibly when assigned to multinational staffs. The proof of having high standards comes from testimony by senior Allied officers about the high quality of Baltic officers who serve on Allied commands in Iraq, Afghanistan, and in Kosovo missions. The Baltic Defence College has repeatedly had positive feedback from senior Allied officers serving in Afghanistan, Iraq, and Kosovo about the quality and competence of the officers from the Baltic States. This is the truest measure of the Baltic Defence College's teaching standards.

\section{Some Core Principles for Multinational Institutions}

\section{The Importance of English Language Education}

While maintaining high academic standards, it is also essential to have a program to provide help to students who meet the standards but, due to problems in English proficiency, have difficulty in completing the academic work. As noted, the students who come to the Baltic Defence College must all possess a solid command of English. But fluency in English does not necessarily mean that the students can express themselves well in writing. On the other hand, despite the prevalence of briefings and PowerPoint, it is still important that officers learn to write clearly. The process of writing forces students into a deeper level of thinking, where they are pushed to lay out analysis, research, and conclusions in written form. To sharpen these critical skills, the Baltic Defence College has writing as one of its five key learning areas. In both the Joint Staff Course and the Higher Command Course the students must carry out a research project and write a research paper in English.

Getting a group of students - almost all of whom have English as their second or third language - to write clearly in English is a tough mission. To get the students up to a high standard, we have a writing program that runs through the whole year. In addition to each student having a faculty advisor for his/her research paper, we have also created a program of additional English classes - especially English writing classes - to help the officers with weak language skills. This takes some additional time and effort in the curriculum, and it also requires hiring specialists who can teach English writing.

The results of the writing program are very positive. Officers with weak skills at the beginning of the year routinely make huge steps in improving their proficiency in English speaking and writing during the course. Some of those who barely passed English at the start of the course have proven to be our top students at the end of the course. The end result is directly in line with our mission. We aim to educate officers who are fully prepared to operate on a multinational staff. After the joint course, each of the Baltic Defence College graduates can not only conduct daily business in fluent English, but he or she can carry also out complex analysis and planning in English. 


\section{Multinational Institutions Can Work, Even Without a Dominant Nation}

I came to the Baltic Defence College having worked in a U.S. military education environment and, at first, it was difficult for me to imagine how an institution that did not have a single lead nation to direct and support all operations could work. In fact, I quickly learned that the Baltic Defence College - an institution owned equally by three nations and lacking a single lead nation — can work very well indeed.

The Baltic Defence College is a consciously multinational institution, and that is one of our great strengths. The Baltic Defence College is answerable to the three defense ministers of the Baltic States. The routine policy management of the college is run through a committee of military and civilian staff of all three Baltic States that meets regularly with the college leadership to deal with higher-level issues (especially the approval of the budget, school organization, and strategic policy and development). For the regular leadership of the college we have a mix of nations in the key leadership positions. The top positions, including the commandant, rotate among the three Baltic States, who appoint the leaders for specific terms of time. For example, the current commandant is an Estonian brigadier general; the director of support is a Latvian Army colonel; the director of the Higher Command Course is a Lithuanian Air Force colonel; and the Dean is an American hired by the Baltic States. Some positions are filled by contributing partner nations: the deputy commandant is a Swedish Army colonel, the director of the Joint Course is an American colonel, the chair of the Operations Department is a Norwegian Air Force colonel, and the chair of the Management and Officership Department is a Finnish lieutenant colonel. We have other faculty members from partner nations, including Denmark, the United Kingdom, and Poland. We have regular guest lecturers from several NATO nations.

The curriculum uses NATO doctrine as the standard, and all activities are conducted in English. In fact, there are only three English-speaking general staff colleges in Europe: those in Great Britain and Ireland, and the Baltic Defence College. By doing everything in English, everything is simplified. Indeed, since NATO operations are conducted in English, and NATO headquarters are multinational, our course is the best possible introduction for any officer who is likely to serve on, or work with, a NATO or multinational headquarters (which is, most likely, almost all of them).

Two-thirds of our students come from the Baltic States, but the rest come from as many as ten other nations, with a mix of students from "old NATO" states (U.S., Norway, Canada, Germany, Denmark) and some from recent partners such as Albania, Georgia, Moldova, Azerbaijan, Bosnia, Croatia, and so on. We mix the students and faculty into the syndicates where most learning and interaction takes place. A typical syndicate might have instructors from a Baltic country and the U.S. to lead it, and have participants from the three Baltic States, other NATO nations, and from non-NATO nations. In a recent discussion on operations in Kosovo, we had students who had served as part of the NATO peacekeeping force as well as Bosnians and Serbians-all expressing their own experiences freely under Chatham House Rules (which means no official attribution). 
When we conduct planning exercises, we have students with a wide variety of experiences - from major powers such as the U.S. and U.K., to very small players who have also participated in various deployments. We have perspectives from several nations, as well as from the full range of armed services. After being in institutions that had a few foreign officers, but were overwhelmingly U.S.-centric, I find the multinational environment at the Baltic Defence College to be very refreshing. Students and faculty find their assumptions challenged more often and more effectively.

One reason why multinational education works is that the Baltic states have all adopted NATO systems and doctrine, as well as Western democratic norms and values in every aspect of the educational process. Such norms require a common professional standard, a Western and democratic understanding of the civil-military relationship, and an exchange of ideas based on Western concepts of academic freedom and discussion. Frankly, any system of multinational education based on any other approach is not likely to work.

\section{Multinational Operations are the Future}

In the future we will be seeing many more multinational peace and intervention operations. Multinational headquarters and operations will be a normal part of the military environment. Officers and civilians will have to be able to operate comfortably in such an environment, and they will need to speak English when they do so. In short, doing well in multinational operations is central to success in the future. The U.S. armed forces are now especially interested in sending officers to the Baltic Defence College in recognition that they need to have more officers prepared for multinational staffs.

The Baltic Defence College has shown that multinational military education can work very well. Other small nations might consider pooling their resources and developing similar courses. The small nations of the Balkans, for example, do not have the resources to offer high-quality higher officer courses for their armed forces. But if countries such as Albania, Montenegro, Croatia, Macedonia, Bosnia and Herzegovina, and Serbia were to pool resources, and use English as a common language, they could reproduce the kind of success the Baltic Defence College has seen. There may well be other regions where small nations can pool resources and develop highly effective higher-level professional officer and civilian courses.

\section{Look After Your Faculty Members}

The former Baltic Defence College commandant, Estonian Brigadier-General Meelis Kiili, had a favorite saying that each year we graduate two groups of exceptional professionals from the Baltic Defence College. The first group is the students who have graduated from our courses. The second group is the faculty members, notably the military faculty seconded by the armed forces to teach for a two- to three-year tour at the college. The second group is just as important as the first because an officer who has served as an instructor in joint operations or strategy for two to three years ought to return to his defense staff as someone who is qualified to the highest level in his/her subject area of 
expertise. The instructor ought to also have a very high level of expertise in joint operational and strategic planning - the core foundation subjects of higher military education.

An instructor at the Baltic Defence College needs to have the opportunity to develop his expertise to such a level that he will be recognized as a valuable asset when he returns from his tour as a faculty member. If instructing is seen as something that enhances one's professional career, then there will be tough competition for defense staffs to send their most promising officers to the Baltic Defence College as instructors as a means of providing an essential step to advancement. Both our institution and the defense ministries will be winners in such a case.

However, making this happen means that an institution of higher military education has to have a comprehensive program of faculty development. To ensure that the faculty maintains currency, a regular program of classes and lectures for the faculty needs to be established. The faculty members also need to develop their own research skills if they are to guide students in their research - so faculty development classes in writing and English are useful. We have found that, in order to give the faculty members the time to develop their professional skills and competence, careful time planning is required, and that regular periods for faculty training and education be set aside.

In addition to general faculty education opportunities, military faculty members also serve as key subject matter experts. Thus, we have found the need to budget the time and money to ensure that every year officers are sent to special short courses in their fields offered at a variety of NATO and national institutions. Short courses of the type offered at military and civilian institutions-I can mention the NATO School at Oberammergau and various excellent short courses taught in the U.K., Netherlands, and U.S. as well as some excellent courses taught by the UN in Geneva and in institutions such as the Geneva Centre for Security Policy - are good examples of courses that help faculty maintain and develop their expertise.

Faculty should also have the time and opportunity to pursue M.A. and even Ph.D. degrees. The Baltic Defence College offers faculty members the chance to obtain a Masters' degrees free of charge through the Latvian National Defence Academy M.A. program in security studies. This fully accredited program ensures that officers in the faculty can take graduate courses in the security field. And, as was mentioned above, Tartu University allows qualified candidates (those who already hold MA and have a high level of fluency in English) the opportunity to earn a Ph.D. in international relations while teaching at the Baltic Defence College.

The policy of graduating two groups - both students and faculty - is very doable and practical, but it cannot be done alone. A truly effective level of faculty development requires both an institutional program to meet the core needs of the institution (such as our classes in English and research) and close cooperation with other military and civilian education institutions that offer the specialized and higher-level courses that we cannot offer. The requirements for time and money are modest, but supporting faculty development cannot be ignored in either scheduling or budget planning. 


\section{The Good News: Quality Military Education Is Inexpensive}

Some Western armed forces today-and I can specifically name the United States as well as other NATO Allies - are looking to make big cuts in their defense budgets. One of the first places to be cut is the military education system. This is a false economy, and will likely save very little money while having disastrous effects on the capabilities of future forces.

Simply put, high-quality military education is cheap. The Baltic Defence College's basic budget - the amount needed to pay some civilian faculty and support personnel, to provide office equipment, cover faculty research, support the library, and provide basic operating expenses - amounts to a couple of million Euros a year. Estonia, the host nation, provides excellent hosting services, a building, and various support services (including housing), as well as paying some support personnel. This total support cost amounts to another couple million Euros worth of support to the College. The cost of officer faculty is borne directly by the armed forces and not the college, and the costs of some civilian faculty are paid by national ministries. Taken all together, with all salaries, costs of supporting officers, etc., the whole cost of the college is still only a few million Euros a year. For this, we graduate eighty to ninety highly educated military officers and civilians every year from our course-for a total cost far below what an elite U.S. or European university would cost.

Part of the low cost is the efficiency that you sometimes get from being a small institution without a large bureaucracy. Part of this efficiency comes from the excellent facilities, faculty expertise, and resources that we can share with the first-rate civilian educational institutions that are located nearby. We also get excellent support from partner institutions in sharing information and databases and so on.

Essentially, a high-quality institution such as the Baltic Defence College costs very little to operate in a year - essentially the cost of a new attack helicopter, or two new battle tanks. Yet, for the price of one helicopter, we can produce as many as ninety graduates who are fully qualified to fulfill their tasks as operational planners and commanders, or to serve in strategic positions. If the Baltic States got rid of their system of higher military education for the price of a few helicopters, would the effectiveness of the national defense of these three countries be enhanced or degraded? I think the answer is clear. While equipment is important, equipment ought not to come at the price of properly trained and educated leaders. No military can function effectively without a highly educated professional leadership cadre. The moral of the story is that seeking defense savings at the cost of military education is the worst possible choice that armed forces can make. 